\title{
Diet variability and reproductive performance of macaroni penguins Eudyptes chrysolophus at Bird Island, South Georgia
}

\author{
Claire M. Waluda*, Simeon L. Hill, Helen J. Peat, Philip N. Trathan \\ British Antarctic Survey, Natural Environment Research Council, High Cross, Madingley Road, Cambridge, CB3 0ET, UK
}

\begin{abstract}
We analysed summer diet and fledging mass of macaroni penguins Eudyptes chrysolophus breeding at Bird Island, South Georgia, during the crèche period (January and February) between 1989 and 2010. Crustaceans were the main prey accounting, for over $90 \%$ of the diet by mass. Antarctic krill Euphausia superba was the main prey, in 17 out of 22 years. Amphipods Themisto gaudichaudii were the main prey in 1994 and 2009, fish in 2004, and the euphausiids Thysanoessa spp. and Euphausia frigida in 2000. There was no clearly dominant prey group in 1999. Prey diversity and the frequency occurrence of T. gaudichaudii both increased with a decreasing proportion of E. superba in the diet. There was strong evidence that macaroni penguins have a sigmoidal functional response, indicating that this kind of response should be accounted for when devising ecosystem-based management reference points for seabirds. The energy and mass of all euphausiids combined (rather than E. superba in particular) in the diet were the most reliable predictors of chick fledging mass; the correlation between model-predicted and observed values was 0.84 . The gross energy content of individual meals was often above average in years when the diets contained fewer euphausiids, but fledging mass was always below average in these years. Although macaroni penguins are able to feed on a variety of prey types, chick growth was always severely impacted by a shortage of euphausiids due to higher energy or time costs associated with feeding on alternative prey types. Given their reliance on euphausiids, macaroni penguins would be particularly vulnerable to potential climate-driven declines in krill stocks.
\end{abstract}

KEY WORDS: Macaroni penguin $\cdot$ Krill $\cdot$ Ecosystem monitoring $\cdot$ Diet $\cdot$ Switching $\cdot$ Functional response $\cdot$ Concorde fallacy

\section{INTRODUCTION}

Marine ecosystems are difficult to sample, but an understanding of ecosystem structure and variability can be developed using data from long-term monitoring studies of selected land-based predators. By examining the diets of predators we can obtain information about their prey preferences, foraging behaviour and ecology. Diets might be expected to reflect the relative abundance or proportion of prey items in the ecosystem, so it is possible to consider predators as integrated indicators of ecosystem structure. Diet data, along with measures of reproductive output can be used to understand predator responses to prey availability (Boyd \& Murray 2001, Reid \& Croxall 2001, Reid et al. 2005a), and are essential for the development of plausible foodweb models (e.g. Murphy et al. 2007a, Hill et al. 2012).

Macaroni penguins Eudyptes chrysolophus have been described as the most important avian consumers in global marine ecosystems, with an estimated consumption of more than 8 million tonnes of 
prey per year (Boyd 2002, Brooke 2004). One of the largest populations of macaroni penguins breeds at South Georgia in the Scotia Sea (Croxall et al. 1984, Williams 1995). The main prey is Antarctic krill Euphausia superba (Barlow et al. 2002), but amphipods and fish can also make up a significant proportion of the diet, particularly in years in which $E$. superba is less readily available in the local environment (Croxall et al. 1999, Waluda et al. 2010).

At Bird Island $\left(54^{\circ} 00^{\prime} \mathrm{S}, 38^{\circ} 02^{\prime} \mathrm{W}\right.$; Fig. 1), located off the north-western tip of South Georgia, the macaroni penguin population consists of around 46500 breeding pairs inhabiting 3 rookery sites (Trathan et al. 2006, 2012). The demography and diet of this population has been regularly monitored since the 1970s. Initial diet samples obtained during the chickrearing periods of 1977, 1980, 1985 and 1986 were dominated by Euphausia superba (between 94 and $98 \%$ by mass) in all years (Croxall \& Prince 1980, Croxall et al. 1988b, 1997). Since 1989, diet data have been collected annually during the crèche period
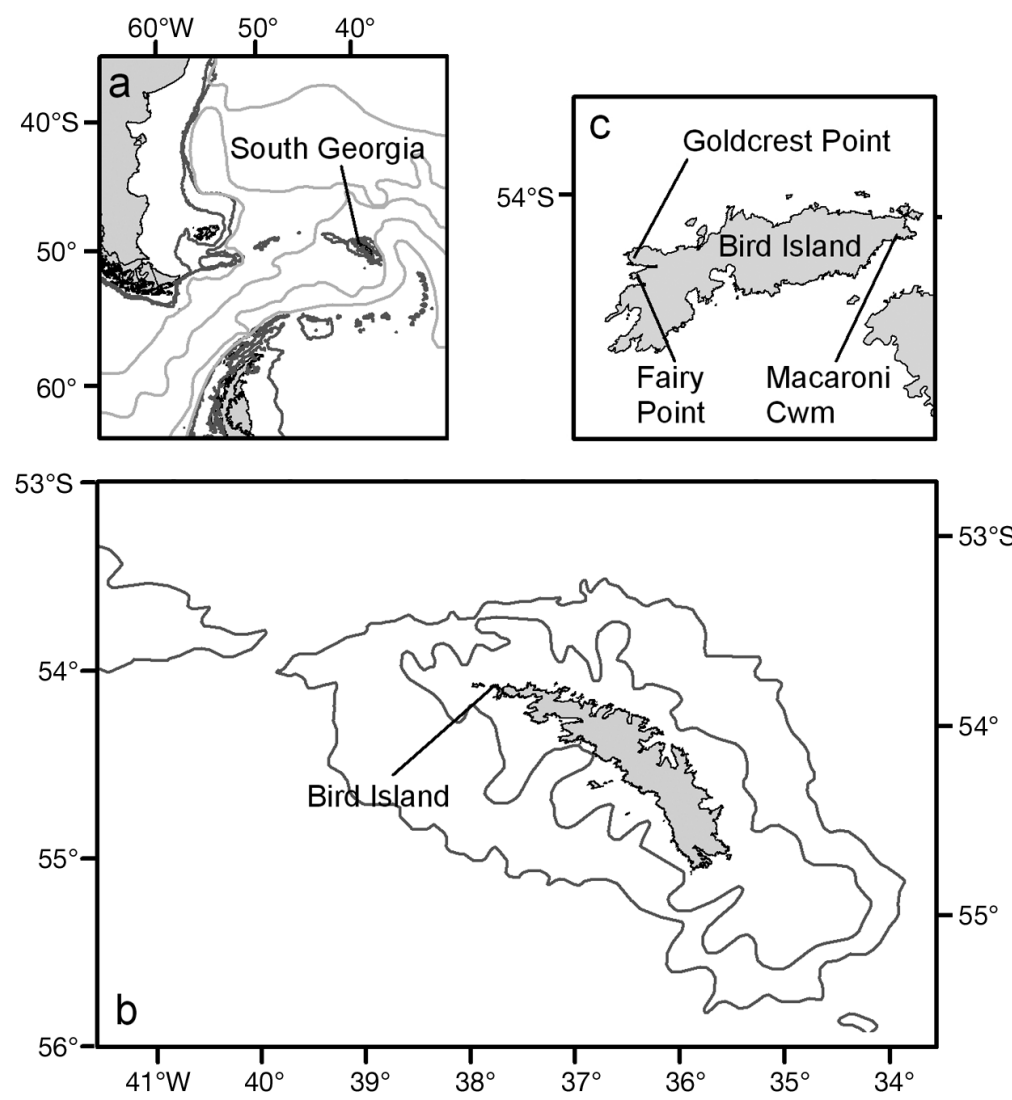

Fig. 1. Northern Scotia Sea with (a) South Georgia and the major fronts of the Antarctic Circumpolar Current (light grey), (b) Bird Island with location of 200 and $1000 \mathrm{~m}$ bathymetric contours shown in dark grey, and (c) Bird Island locations of macaroni penguin colonies at Goldcrest Point ( 35000 pairs), Fairy Point ( 500 pairs) and Macaroni Cwm ( 11000 pairs) using standardised methods (CCAMLR 2004) as part of the Commission for the Conservation of Antarctic Marine Living Resources (CCAMLR) Ecosystem Monitoring Programme (CEMP) (Agnew 1997). The objective of CEMP is to detect changes in the Southern Ocean ecosystem and to distinguish the potential effects of commercial fishing from other drivers of change.

Macaroni penguins are diving predators, making the majority of their dives during the day to median depths of between 10 and $60 \mathrm{~m}$ (Croxall et al. 1988a, 1993, Hart et al. 2010). The main feeding region for the population breeding at Bird Island is to the northwest of the island (Trathan et al. 2006, Waluda et al. 2010). Energy is delivered to the chick as regurgitated stomach contents, with both parents undertaking foraging trips while the chicks are at the crèche stage (Barlow \& Croxall 2002).

Here, we describe the diets of macaroni penguins during crèche for the $22 \mathrm{yr}$ period from 1989 to 2010. While macaroni penguins breeding at Bird Island have been described as 'dependent predators' of Euphausia superba (Croxall \& Prince 1987, Reid et al. 1999a), some studies have reported a decline in the relative proportion of E. superba in macaroni penguin diets since the late 1980s (Reid \& Croxall 2001, Barlow et al. 2002). Both of these earlier analyses considered data from 1989 to 2000, and by doubling the length of the time series, we are able to better understand these observations in the context of long-term variability. We examine individual and inter-annual variability in diet composition and prey dominance and assess the influence of diet on fitness using the mass of chicks at fledging as an indicator of reproductive output.

\section{MATERIALS AND METHODS}

\section{Diet sampling}

Diet samples were obtained from macaroni penguins at the Goldcrest Point colony, Bird Island, South Georgia (Fig. 1). Samples were obtained during the crèche period (January and February) from 1989 to 2010, using the stomach lavage methods described in Wilson (1984) and Williams (1991). Samples were usually obtained over a 4 wk period with 10 birds sampled each 
week as they returned to the colony to feed their chicks (Table 1). All diet sampling procedures used were regulated by the British Antarctic Survey Ethical Review Committee in collaboration with Cambridge University and the UK Home Office.

Each diet sample was drained through 2 sieves $(3.35$ and $250 \mu \mathrm{m})$ and weighed to calculate wet meal mass per penguin. No samples were recorded as empty stomachs. Each sample was then sorted into the crustacean, fish and cephalopod components and the constituent parts weighed. Crustaceans were identified to species where possible. Fish otoliths were separated and counted from all diet samples, used to identify fish species and to calculate lengths using regression equations (Reid \& Arnould 1996). Cephalopods were identified from beaks by comparison with a reference collection held at the British Antarctic Survey, with regression equations used to relate the lower rostral length to the original mantle length where possible (Clarke 1986, Rodhouse et al. 1990). The number of prey species observed in each year was recorded.

\section{Mean mass at fledging}

The mean mass of chicks at fledging in each year was used as a simple index of reproductive performance for the population of macaroni penguins breeding at Bird Island. Annual fledging mass was calculated as the mean mass of approximately 100 fledging birds sampled just prior to their departure from the colony (mid-February) each year. Fledging weights were obtained from the smaller macaroni penguin colony (approximately 500 pairs of breeding birds) at Fairy Point, adjacent to the Goldcrest Point colony (approximately 35000 pairs) (Fig. 1). As part of the Bird Island long-term monitoring programme, macaroni penguin de-

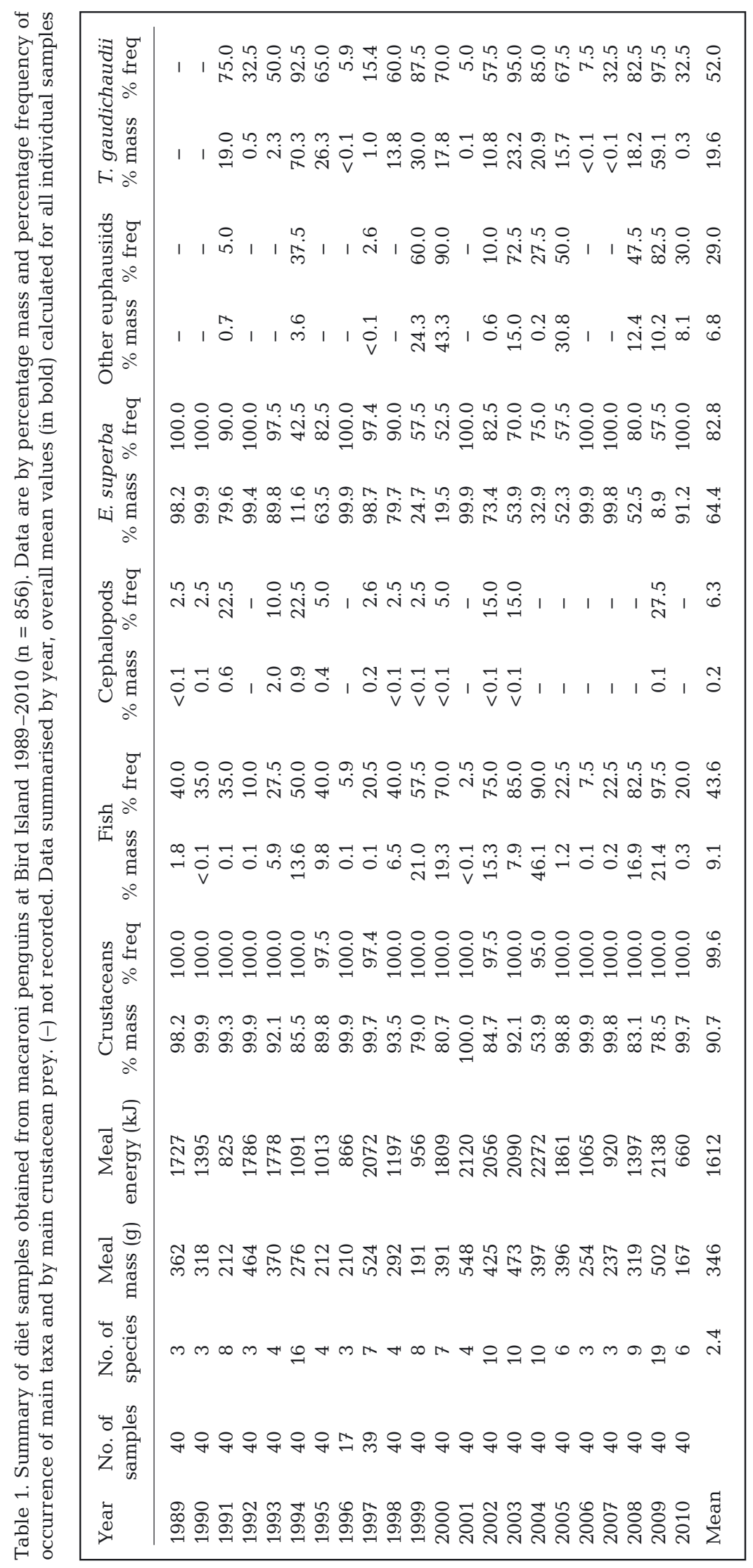


mographic data are obtained from the Fairy Point colony, which is a satellite of the Goldcrest Point colony. Birds from both colonies use the same foraging areas and access the open ocean via the same inlet (Trathan et al. 2006).

\section{Energy content of meals}

The energy content of each meal was calculated from the wet mass of each prey component and published data on energy content $\left(\mathrm{kJ} \mathrm{g}^{-1}\right)$ of prey, assuming a constant mass-energy conversion for each prey type. Energy values from the same area and season (Scotia Sea during austral spring) were used whenever possible, but equivalent values from other areas and seasons were used as necessary. The energy content of Euphausia superba was calculated using a mean value for males and females (Clarke 1980). A single energy value was used for each of: euphausiids other than E. superba, based on Thysanoessa macura (Torres et al. 1994); amphipods, based on Themisto gaudichaudii (Ciancio et al. 2007); and cephalopods, based on a mean value for muscular squid (Clarke et al. 1985) (Table 2). The energy content of fish was calculated based on the species composition for each year, with energy values for key species given in Table 2. In years in which fish flesh was present but could not be identified to species level (i.e. years in which no otoliths were recovered) a mean value of $5.83 \mathrm{~kJ} \mathrm{~g}^{-1}$ (the mean of all fish species listed in Table 2) was used to calculate the energy content of fish.

\section{Analyses}

In this study we (1) describe the frequency of occurrence, meal mass, energy and diversity of prey in individual diets, (2) examine variability in diet composition and prey dominance within and between years, and (3) examine the relationship between diet and the mean mass of chicks at fledging. Non-linear least squares analyses were used to examine the relationship between meal composition and fledging weights. Analyses were done in the statistical package R (v2.13; R Development Core Team 2011). We used the corrected Akaike Information Criterion $\left(\mathrm{AIC}_{\mathrm{C}}\right)$ and calculated the correlations between modelled and observed values to compare 24 models of the relationship between diet, indicated by various metrics, and fledging mass. The diet metrics included were the meal mass (wet mass in grams) or energy content (kJ) of each prey group and all groups combined, and the model forms included both 2- and 3-parameter asymptotic models.

\section{RESULTS}

\section{Individual diet variability}

In total, 856 diet samples were obtained from macaroni penguins between 1989 and 2010. Meals comprised crustaceans, fish and cephalopods, with crustaceans occurring in 853 diet samples (99.6\%), and the remaining 3 samples containing only fish. The

Table 2. Energy content for key prey species of macaroni penguins

\begin{tabular}{|c|c|c|c|c|}
\hline & Family & Species & Energy $\left(\mathrm{kJ} \mathrm{g}^{-1}\right)$ & Source \\
\hline Cephalopods & \multicolumn{2}{|c|}{ [See Table 3 for species names] } & 4.27 & Clarke et al. (1985) \\
\hline \multirow[t]{8}{*}{ Fish } & Channichthyidae & $\begin{array}{l}\text { Champsocephalus gunnari } \\
\text { Pseudochaenichthys georgianus }\end{array}$ & $\begin{array}{l}5.4 \\
4.55\end{array}$ & $\begin{array}{l}\text { Lea et al. (2002) } \\
\text { Vanella et al. (2005) }\end{array}$ \\
\hline & Gempylidae & Paradiplospinus gracilis & 4.6 & Cherel \& Ridoux (1992) \\
\hline & \multirow[t]{5}{*}{ Myctophidae } & Electrona antarctica & 7.93 & Donnelly et al. (1990) \\
\hline & & Electrona carlsbergi & 6.57 & Clarke \& Prince (1980) \\
\hline & & Krefftichthys anderssoni & 8.23 & $\begin{array}{l}\text { Cherel \& Ridoux 1992, Tierney } \\
\text { et al. (2002) (mean value) }\end{array}$ \\
\hline & & Protomyctophum bolini & 6.1 & $\begin{array}{l}\text { Data for P. tenisoni used; } \\
\text { Lea et al. (2002) }\end{array}$ \\
\hline & & Protomyctophum choriodon & 6.1 & $\begin{array}{l}\text { Data for } P \text {. tenisoni used; } \\
\text { Lea et al. (2002) }\end{array}$ \\
\hline & Nototheniidae & Lepidonotothen larseni & 4.9 & Staniland et al. (2007) \\
\hline \multirow[t]{3}{*}{ Crustaceans } & \multirow[t]{2}{*}{ Euphausiidae } & Euphausia superba & 4.645 & $\begin{array}{l}\text { Clarke (1980) (mean of male } \\
\text { and female) }\end{array}$ \\
\hline & & Thysanoessa macura & 5.038 & Torres et al. (1994) \\
\hline & Hyperiidae & Themisto gaudichaudii & 3.1 & Ciancio et al. (2007) \\
\hline
\end{tabular}


crustacean component was dominated by euphausiids, in particular Euphausia superba, which was present in 709 samples (83\%). Other species of euphausiids (E. frigida and Thysanoessa spp.; not always identified to species level so included here as a single prey group) were present in 248 samples ( $29 \%$ ), and the hyperiid amphipod Themisto gaudichaudii was present in 445 samples (52\%).

Fish remains were present in 373 diet samples (44\%). A total of 11 species of fish from 6 families were identified, with Champsocephalus gunnari and Krefftichthys anderssoni the most frequently recorded species (Table 3). Mean estimated standard lengths were between $26 \mathrm{~mm}$ (Muraenolepis microps) and $278 \mathrm{~mm}$ (Paradiplospinus gracilis) (Table 3).

Cephalopod remains were present in 54 diet samples $(6 \%)$. A total of 7 cephalopod species from 5 families were identified, with Kondakovia longimana the most frequently recorded species (Table 3). Estimated mean mantle lengths were between $41 \mathrm{~mm}$ (K. longimana) and $200 \mathrm{~mm}$ (Martialia hyadesi) (Table 3).

The mean $( \pm \mathrm{SD})$ mass of all 856 diet samples was $346 \pm 214 \mathrm{~g}$ (Table 1, Fig. 2a). The diet was composed of crustaceans $(314 \pm 212 \mathrm{~g})$, fish $(32 \pm 86 \mathrm{~g})$ and cephalopods $(0.6 \pm 9 \mathrm{~g})$. The most common crustacean prey were Euphausia superba $(236 \pm 231 \mathrm{~g})$,

Table 3. Prey species recorded in the diet of macaroni penguins from 1989 to 2010. Mean length is given as standard length for fish and mantle length for cephalopods. (-) data not available

\begin{tabular}{|c|c|c|c|c|c|c|c|}
\hline & Family & Species & $\begin{array}{l}\text { No. of } \\
\text { years }\end{array}$ & $\begin{array}{c}\text { No. of } \\
\text { samples }\end{array}$ & $\begin{array}{l}\text { Frequency } \\
(\%)\end{array}$ & $\begin{array}{c}\text { Mean } \\
\text { length } \\
(\mathrm{mm})\end{array}$ & $\begin{array}{l}\text { Years } \\
\text { present } \\
\text { in diet }\end{array}$ \\
\hline \multirow[t]{7}{*}{ Cephalopods } & Brachioteuthidae & Brachioteuthis picta & 2 & 4 & 0.47 & - & 1991, 1994 \\
\hline & Cranchidae & Galiteuthis glacialis & 1 & 1 & 0.12 & - & 2002 \\
\hline & Onychoteuthidae & Kondakovia longimana & 3 & 33 & 3.86 & 41 & $1991,1994,2009$ \\
\hline & Ommastrephidae & Martialia hyadesi & 4 & 22 & 2.57 & 200 & $\begin{array}{c}1991,1994,2002 \\
2003\end{array}$ \\
\hline & Onychoteuthidae & Moroteuthis knipovitchi & 1 & 1 & 0.12 & 158 & 2009 \\
\hline & Psychroteuthidae & Psychroteuthis glacialis & 1 & 2 & 0.23 & - & 2009 \\
\hline & Brachioteuthidae & Slosarczykovia circumantarctica & 1 & 3 & 0.35 & - & 2009 \\
\hline \multirow[t]{11}{*}{ Fish } & Bathydraconidae & Parachaenichthys georgianus & 1 & 1 & 0.12 & 238 & 2004 \\
\hline & Channichthyidae & Champsocephalus gunnari & 13 & 87 & 10.16 & 132 & $\begin{array}{c}1993-95,1997 \\
1999,2000 \\
2002-05,2008-10\end{array}$ \\
\hline & Channichthyidae & Pseudochaenichthys georgianus & 2 & 8 & 0.93 & 165 & 1994, 2003 \\
\hline & Gempylidae & Paradiplospinus gracilis & 1 & 1 & 0.12 & 278 & 2009 \\
\hline & Muraenolepididae & Muraenolepis microps & 2 & 18 & 2.10 & 26 & 2008,2009 \\
\hline & Myctophidae & Electrona antarctica & 8 & 50 & 5.84 & 45 & $\begin{array}{c}1994,2000-05 \\
2009\end{array}$ \\
\hline & Myctophidae & Electrona carlsbergi & 4 & 8 & 0.93 & 69 & 2002-04, 2009 \\
\hline & Myctophidae & Krefftichthys anderssoni & 8 & 80 & 9.35 & 59 & $\begin{array}{c}1994,1998,1999 \\
2002,2004 \\
2008-10\end{array}$ \\
\hline & Myctophidae & Protomyctophum bolini & 1 & 1 & 0.12 & 63 & 2009 \\
\hline & Myctophidae & Protomyctophum choriodon & 7 & 20 & 2.34 & 81 & $\begin{array}{l}1994,1997,1999 \\
2003,2004,2008, \\
2009\end{array}$ \\
\hline & Nototheniidae & Lepidonotothen larseni & 10 & 41 & 4.79 & 99 & $\begin{array}{c}1994,1997,1999 \\
2001-05,2007 \\
2009\end{array}$ \\
\hline \multirow[t]{7}{*}{ Crustaceans } & Euphausiidae & Euphausia superba & 22 & 709 & 82.83 & 42 & 1989-2010 \\
\hline & Euphausiidae & E. frigida/Thysanoessa spp. & 12 & 248 & 28.97 & - & $\begin{array}{c}1991,1994,1997 \\
1999,2000 \\
2002-05,2008-10\end{array}$ \\
\hline & Hyperiidae & Themisto gaudichaudii & 20 & 445 & 51.99 & - & 1991-2010 \\
\hline & Bougisidae & Primno macropa & 1 & 2 & 0.23 & - & 2009 \\
\hline & Crangonidae & Notocrangon spp. & 2 & 3 & 0.35 & - & 1997,2009 \\
\hline & Calanoida & Euchaeta antarctica & 2 & 2 & 0.23 & - & 2008, 2009 \\
\hline & Calanoida & Rhincalanus gigas & 2 & 2 & 0.23 & - & 2008, 2009 \\
\hline
\end{tabular}



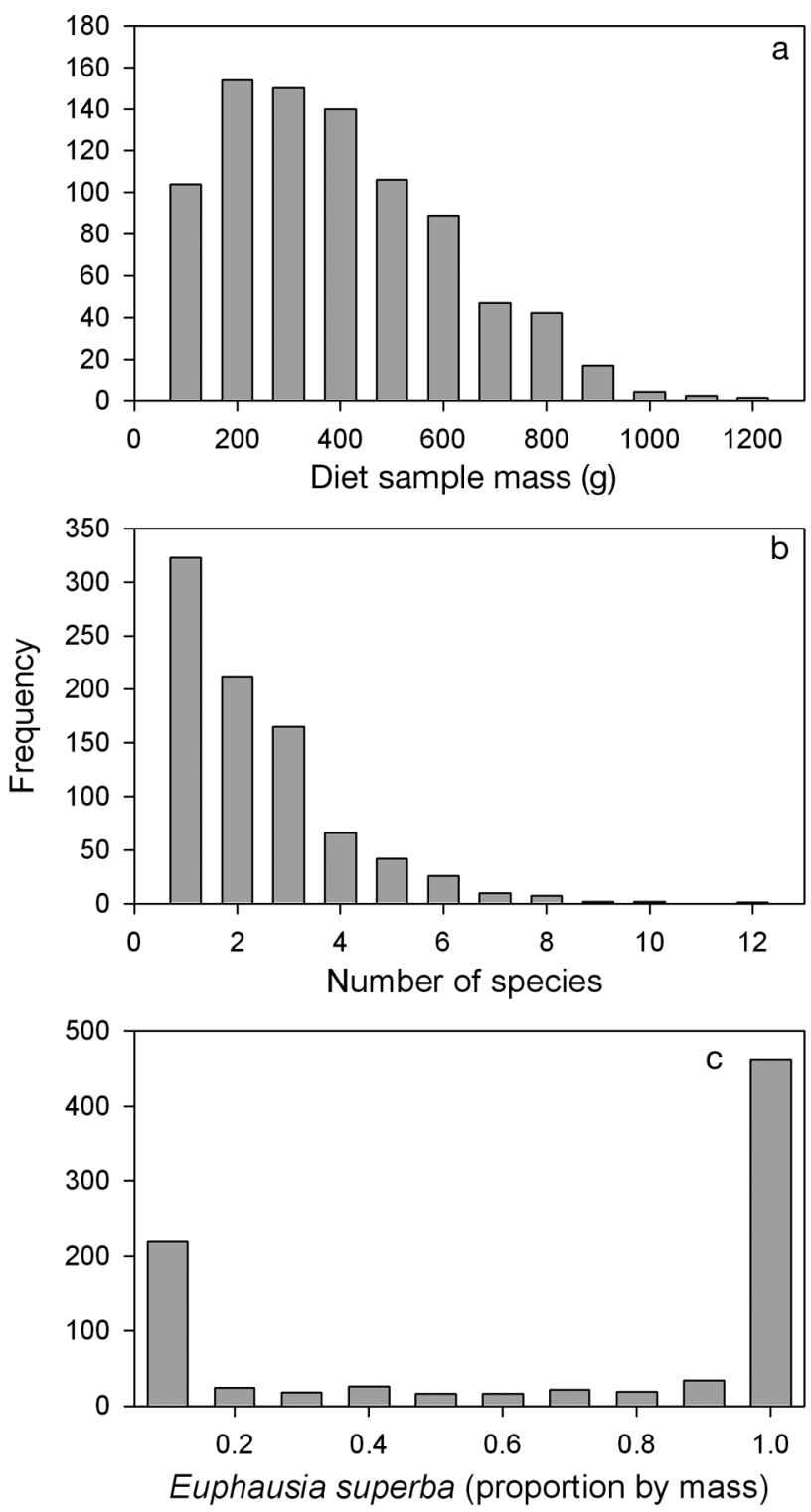

Fig. 2. Frequency occurrence of (a) diet sample mass, (b) number of species per sample and (c) proportion of Euphausia superba in diet samples

Themisto gaudichaudii $(53 \pm 116 \mathrm{~g})$ and euphausiids other than E. superba $(25 \pm 85 \mathrm{~g})$. The mean energy derived from meals was $1612 \pm 1061 \mathrm{~kJ}$ (Table 1). The number of prey species recorded per sample was between 1 and 12 (mean \pm SD: $2.4 \pm 1.6$ ) (Fig. 2b).

Euphausia superba was the main prey, but the proportion of this species in diets showed a distinct bimodal distribution, with 147 diet samples (17\%) containing no E. superba and 277 (32\%) containing only E. superba (Fig. 2c). To further examine prey dominance in diets we combined data into 3 main prey groups, these were 'euphausiids' (E. superba, E. frigida, Thysanoessa spp.), 'other crustaceans' (mostly amphipods; see Table 3 ) and 'fish'. In total, 357 of the 856 individual diet samples (42\%) were composed entirely of a single prey type (317 were euphausiids, 37 other crustaceans, 3 fish). In 627 diet samples (73\%), a single prey type represented $>90 \%$ of diet mass (502 samples with euphausiids, 100 other crustaceans, 25 fish). We refer to this type of diet as 'dominated' by the majority prey type. Only 229 samples $(27 \%$ ) had no dominant prey type. We shall refer to this latter category as 'mixed' diets. All but 3 of these mixed diets included euphausiids.

\section{Annual patterns of variability}

Annual meal mass (mean $\pm \mathrm{SD}$ ) ranged between $167 \pm 110 \mathrm{~g} \mathrm{(2010)}$ and $548 \pm 240 \mathrm{~g}$ (2001). Annual meal energy ranged between $660 \pm 441 \mathrm{~kJ}(2010)$ and $2270 \pm 1250$ kJ (2004) (Fig. 3, Table 1). Euphausia superba was recorded in all 22 years, other species of euphausiids were present in 12 years and Themisto gaudichaudii was recorded in 20 years (Table 1). Fish were recorded in the diet in all 22 years, with otoliths recovered and species identified in 16 years (no species data were available for 1989 to 1992, 1996, 2006; see also Table 3). Cephalopods were present in 13 years (Table 1), with cephalopod beaks recovered in 5 years (1991, 1994, 2002, 2003，2009; Table 3). E. superba was the main prey species $(>50 \%$ of the annual total recorded diet mass) in 17 years, but contributed less than one third in 5 years (Fig. 4). There was no trend in the proportion of E. superba in the diet over the period of the study $(r=0.03 . p=0.45)$ and the 5 yr moving average indicates that this proportion has remained fairly constant at around $68 \%$ since the mid-1990s (Fig. 4). The proportion by mass of E. superba was negatively correlated with both the frequency of $T$. gaudichaudii (arcsine transformed data; $\mathrm{r}=-0.88, \mathrm{p}<0.01$ ) and the number of species in the diet ( $E$. superba data were arcsine transformed; $\mathrm{r}=-0.81, \mathrm{p}<0.01)$.

Inter-annual patterns in prey dominance are shown in Fig. 5. The most common situation was where more than $75 \%$ of diets were euphausiiddominated (10 of 22 years). In 4 of these 10 years, $100 \%$ of diets were euphausiid-dominated. In 5 years, less than $25 \%$ of diets were euphausiiddominated, and the remaining diets were either mixed ( 3 to $73 \%$ of diets) or dominated by other crustaceans ( 0 to $50 \%$ ) or fish ( 0 to $23 \%$ ). In 7 years, 


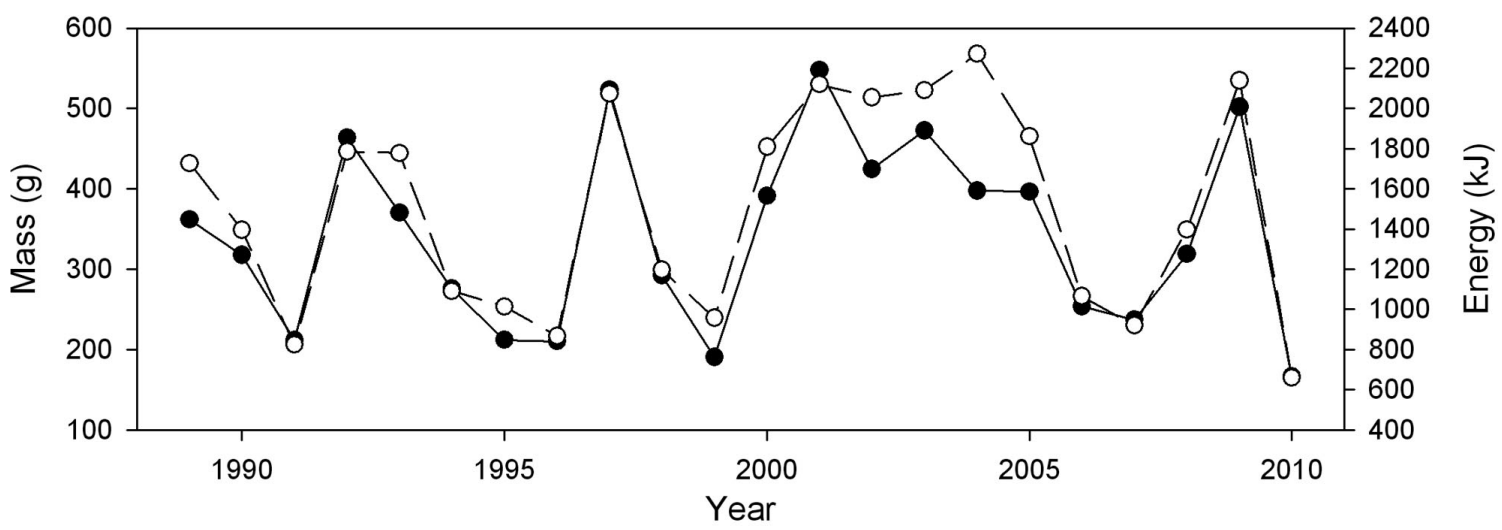

Fig. 3. Annual variability in meal mass (•) and energy derived from meals (O) of macaroni penguins 1989-2010

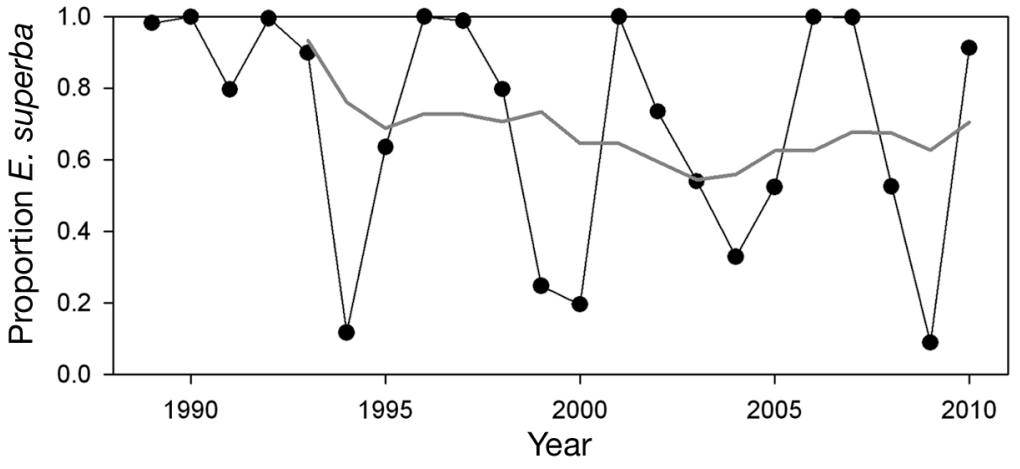

Fig. 4. Proportion of Euphausia superba (by mass) in the diet of macaroni penguins from 1989 to 2010. Grey line indicates 5 yr moving average $($ mean $=0.68)$

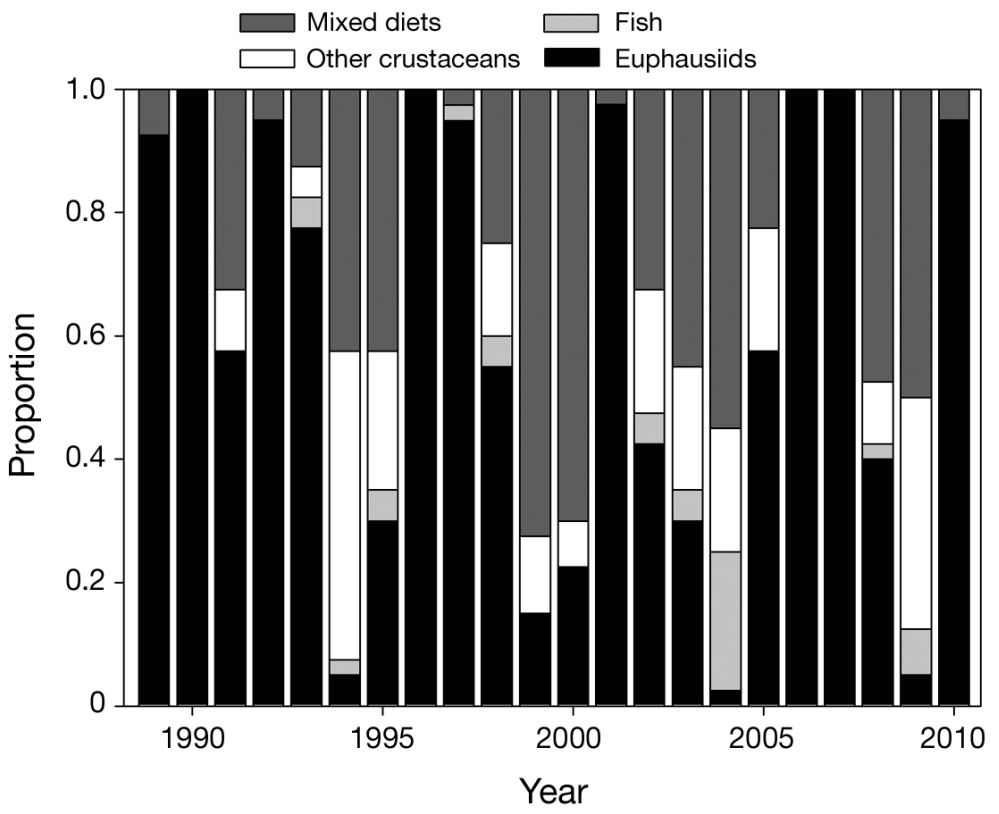

Fig. 5. Composition of macaroni penguin diets from 1989 to 2010. Diets are categorised as dominated ( $>90 \%$ of a diet sample) by euphausiids, other crustaceans (mostly amphipods, Themisto gaudichaudii) or fish or as mixed diets where no individual prey group contributed $>90 \%$ between 25 and $75 \%$ of diets were euphausiid-dominated, 23 to $55 \%$ were mixed, 8 to $50 \%$ were dominated by other crustaceans, and 0 to $5 \%$ were fish-dominated. Within years, the percentage of mixed diets varied between 0 (in 1990, 1996, 2006, 2007; Fig. 5) and $73 \%$ (1999). There were inevitable negative correlations between the proportion of euphausiid-dominated diets and the proportion of diets that were dominated by other crustaceans (arcsine transformed data; $r=-0.83, p<0.01$ ) or fish (arcsine transformed data; $\mathrm{r}=$ $-0.55, \mathrm{p}<0.01$ ), or were mixed (arcsine transformed data; $\mathrm{r}=-0.94, \mathrm{p}<0.01$ ).

\section{Relationships between diet and fledging mass}

The mean mass of chicks at fledging varied between 2.9 and $3.5 \mathrm{~kg} \mathrm{yr}^{-1}$ (mean $\pm \mathrm{SD}=3.27 \pm 0.18$ kg; Fig. 6) Fledging mass was positively correlated with meal mass and energy, and with the crustacean, Euphausia superba and euphausiid components of the diet, but it was negatively correlated with the amphipod and fish components (Fig. 7). AIC $_{\mathrm{C}}$ provided most support for 3-parameter models with either mass or energy content of all euphausiids as the independent variable. The correlation between modelpredicted and observed values for fledging weight was 0.84 for both of these models (Fig. 7, Table 4). $\mathrm{AIC}_{\mathrm{C}}$ 


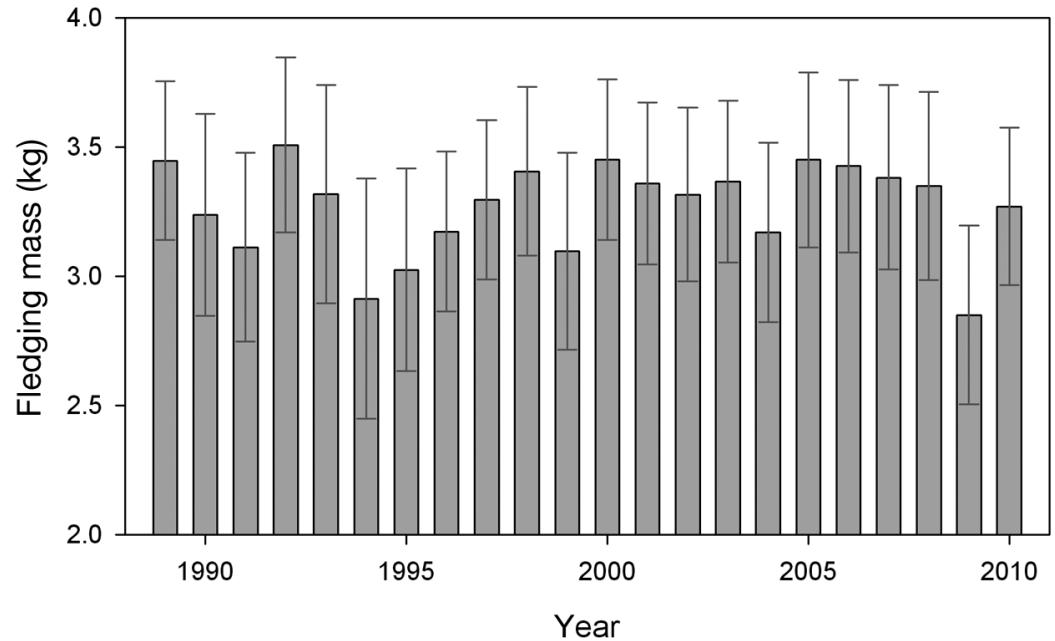

Fig. 6. Mean $( \pm \mathrm{SD})$ annual fledging mass of macaroni penguins from 1989 to 2010. Overall mean $=3.27 \mathrm{~kg}$

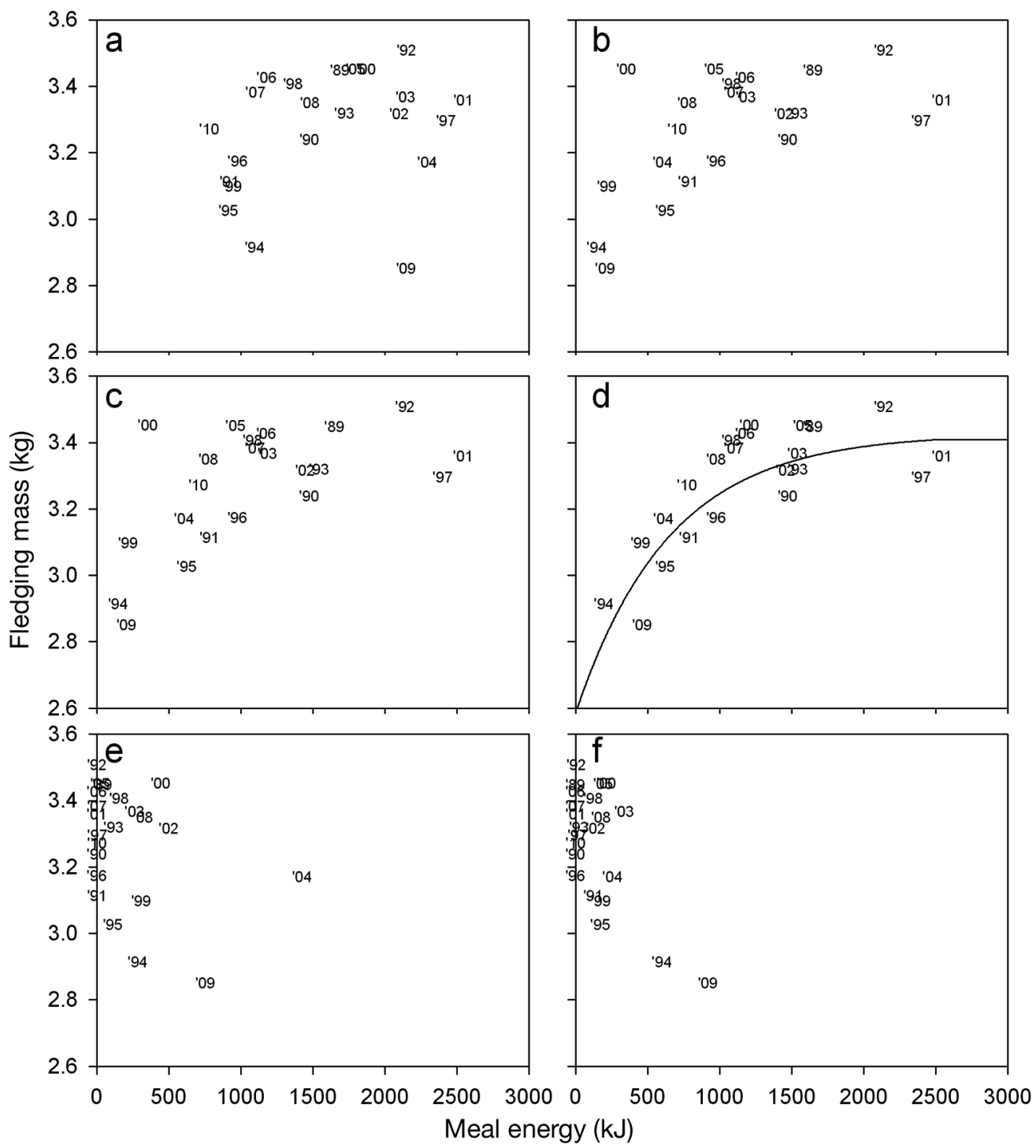

Fig. 7. Relationship between energy derived from diet $(\mathrm{kJ})$ and fledging mass of macaroni penguins where meal energy is derived from (a) total diet, (b) all crustaceans, (c) Euphausia superba only, (d) all euphausiids (solid line shows fitted 3-parameter model, see Table 4), (e) fish only, or (f) Themisto gaudichaudii only 
Table 4. Results of model fitting (diet versus fledging weight) using 2- and 3-parameter non-linear least squares analysis. $x$ is calculated as either wet mass $(\mathrm{g})$ or energy derived from prey $(\mathrm{kJ})$ for each prey group and all diet components combined. Bold: best fit for each parameter (corrected Aikaike Information Criteria $\left.\left[\mathrm{AIC}_{\mathrm{c}}\right]\right)$. The correlation between model-predicted and observed values for fledging weight is also given for each model. Models - 3-parameter: fledging.wt $\approx \mathrm{a}-$ $\mathrm{b} \cdot \exp (-\mathrm{c} \cdot \mathrm{x}) ; 2$-parameter: fledging.wt $\approx \mathrm{a} \cdot[1-\exp (-\mathrm{c} \cdot \mathrm{x})]$, where $\mathrm{a}$, $\mathrm{b}$ and $\mathrm{c}$ are model parameters

\begin{tabular}{|lccccc|}
\hline & df & \multicolumn{2}{c}{ Meal mass (g) } & \multicolumn{2}{c|}{$\begin{array}{c}\text { Meal energy (kJ) } \\
\end{array}$} \\
& & $\mathrm{AIC}_{\mathrm{c}}$ & Correlation & $\mathrm{AIC}_{\mathrm{c}}$ & Correlation \\
\hline 3 parameters & 4 & 295.51 & 0.31 & 294.29 & 0.38 \\
All diet components & 4 & 293.27 & 0.43 & 288.44 & 0.59 \\
All crustaceans & 4 & 282.17 & 0.71 & 282.17 & 0.71 \\
E. superba & 4 & 271.01 & 0.84 & $\mathbf{2 7 0 . 8 4}$ & $\mathbf{0 . 8 4}$ \\
All euphausiids & 4 & 284.21 & 0.68 & 284.21 & 0.68 \\
Amphipods (T. gaudichaudii) & 4 & 294.66 & 0.36 & 294.31 & 0.38 \\
All fish & & & & & \\
2 parameters & 3 & 293.72 & 0.30 & 292.35 & 0.38 \\
All diet components & 3 & 291.69 & 0.41 & 287.18 & 0.57 \\
All crustaceans & 3 & 282.31 & 0.68 & $\mathbf{2 8 2 . 3 1}$ & $\mathbf{0 . 6 8}$ \\
E. superba & 3 & 288.98 & 0.51 & 289.17 & 0.51 \\
All euphausiids & 3 & 282.93 & 0.66 & 282.93 & 0.66 \\
Amphipods (T. gaudichaudii) & 3 & 292.98 & 0.34 & 292.81 & 0.35 \\
All fish & 3 & & & & \\
\hline
\end{tabular}

\section{DISCUSSION}

\section{Crustacean dominance and variability in the contribution of Euphausia superba}

This work presents data from $22 \mathrm{yr}$ of diet sampling of macaroni penguins Eudyptes chrysolophus breeding at Bird Island, South Georgia. This is one of the longest and most comprehensive time series of penguin diet data available globally. Crustaceans dominated the diet, with Antarctic krill Euphausia superba the most commonly eaten prey species. The amount of E. superba in the diet was variable from year to year, providing over half of the diet by mass in 17 years of the study but less than one third in 5 years. Previous work has reported a decline in E. superba in macaroni penguin diets at Bird Island for the period between 1989 and 2000 (Reid \& Croxall 2001, Barlow et al. 2002). Our Fig. 4 confirms low values (1999 and 2000) at the end of this period but, as with 1994 and 2009, these low values were followed by an immediate recovery.

The years in which Euphausia superba made up $>99 \%$ of the diet by mass occurred at approximately $5 \mathrm{yr}$ intervals $(1992,1996,2001,2006,2007)$. This is likely to be related to increased local abundance due to pulses of E. superba recruitment into the South Georgia ecosystem (Reid et al. 1999b, 2002, Murphy \& Reid 2001, Murphy et al. 2007a,b). Similar patterns of E. superba recruitment have been reported in the diets of gentoo and chinstrap penguins breeding at Livingston Island in the South Shetland Islands (Miller \& Trivelpiece 2007). The availability of E. superba was probably low in the South Georgia ecosystem in the 5 years when it made up less than one third of the diet of macaroni penguins (1994, 1999, 2000, $2004,2009)$, with similarly low estimates of abundance in data from acoustic surveys and other predator diets (Croxall et al. 1999, Xavier et al. 2003, Waluda et al. 2010, S. Fielding pers. comm.).

Crustaceans other than Euphausia superba were the main prey in 3 years, with small euphausiids (E. frigida, Thysanoessa spp.) the most common prey group in 2000 and the hyperiid amphipod Themisto gaudichaudii dominant in 1994 and 2009. The results of our study are consistent with diet studies of macaroni penguins and the closely related royal penguins Eudyptes schlegeli elsewhere in the Southern Ocean where crustaceans (particularly euphausiids) are frequently recorded as the main prey (Table 5).

\section{Fish and cephalopods in the diet}

The majority of fish species recorded in diet samples occupy a pelagic or bentho-pelagic habitat, with the most commonly recorded species including the myctophid Krefftichthys anderssoni, the channichthid Champsocephalus gunnari and the notothenid Lepidonotothen larseni. Similar species fish have been reported in varying proportions in the diets of Antarctic fur seals (Reid \& Arnould 1996, Reid et al. 2006), gentoo penguins (Hill et al. 2005, Reid et al. 2005b), and black-browed and grey-headed albatrosses (Reid et al. 1996, Xavier et al. 2003), which also breed at Bird Island. Fish can provide a significant proportion of the diet of macaroni and royal penguins breeding at other locations (Table 5). Myctophids, particularly $K$. anderssoni, Protomyctophum tenisoni, P. normani and Electrona carlsbergi (Brown \& Klages 1987, Hindell 1988, Ridoux 1994, Green et al. 1998, Pichegru et al. 2011) are the most commonly observed fish in the diets of macaroni penguins throughout the 


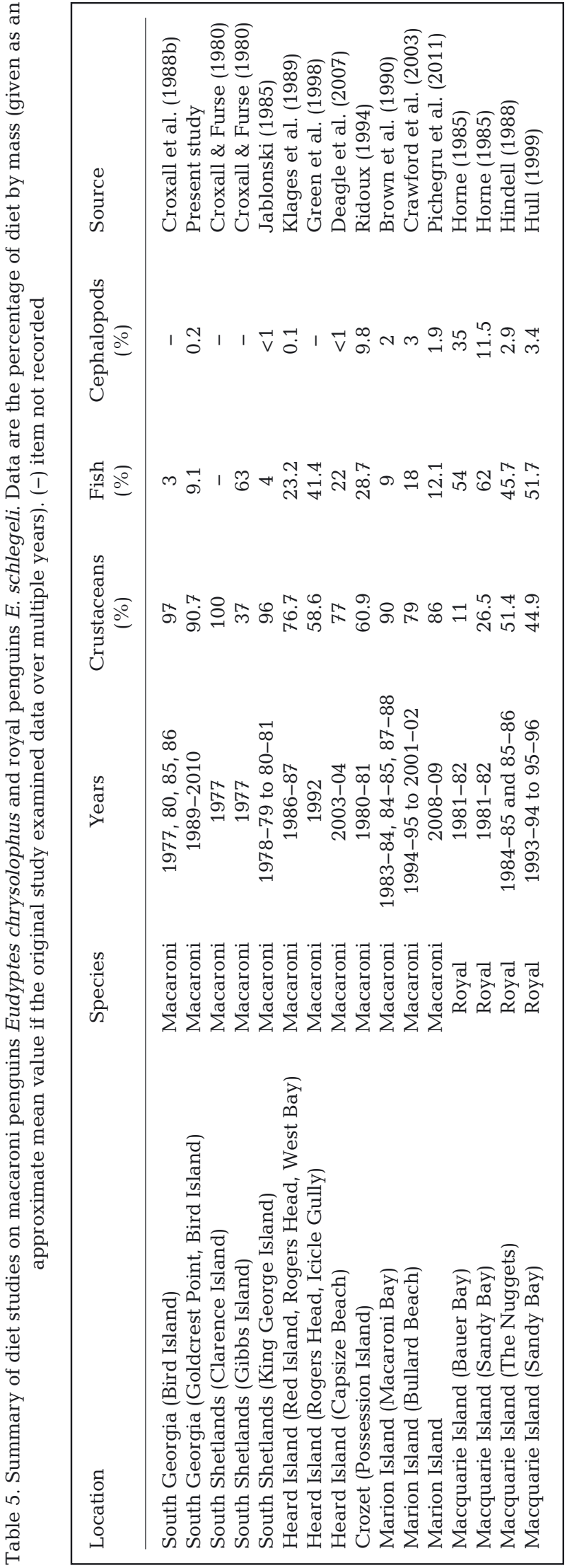

Southern Ocean, and C. gunnari is also important at Heard Island in certain years (Klages et al. 1989).

Cephalopods were rare in diet samples, and only 2 species (Martialia hyadesi and Kondakovia longimana) were present in 3 or more years of the study. Cephalopods were more common in years during which Euphausia superba was not a dominant prey group, particularly 2009, when the lowest amount of E. superba and the highest diversity of species were recorded. A number of cephalopod (and other) species not seen in other years were recorded in 2009 (Table 3). While cephalopods can make up a reasonable proportion of the diet of some species, e.g. king penguins Aptenodytes patagonicus, emperor penguins A. forsteri and little penguins Eudyptula minor (Croxall \& Prince 1996), they probably occur in waters beyond the diving depth and range of breeding macaroni penguins except during unusual years. Cephalopods are similarly rare in the diets of macaroni penguins breeding at other locations in the South Atlantic, but can contribute a significant proportion of the diet at colonies in the Southern Indian Ocean (Table 5), with $K$. longimana the most commonly observed species at Crozet Island and Marion Island (Adams \& Brown 1989, Ridoux 1994), and Moroteuthis spp. the most common cephalopod in the diets of royal penguins breeding at Macquarie Island (Hindell 1988).

\section{Prey preferences}

A greater variety of species was observed in the diet as the proportion of Euphausia superba declined. In years of very low E. superba (e.g. 1994, 2009) diet diversity was very high (Table 1). Macaroni penguins have previously been described as 'prey switchers' based on observations that they mainly feed on euphausiids but can feed on other prey when euphausiids are scarce (Croxall et al. 1999). Technically, the term 'prey switching' describes a tendency for predators to preferentially consume common prey types disproportionately more than less common prey types (Murdoch 1969). The term is usually applied to individual predators and is associated with a sigmoidal (type III) functional response, in which the predator's intake of a single prey type is disproportionately low at low densities, but increases rapidly to saturation as density increases (Holling 1959). Our analysis shows that the majority of individual diets were dominated by euphausiids, and there were 4 years in which every observed diet was euphausiid-dominated. This sug- 
gests that all individual macaroni penguins at Bird Island were euphausiid specialists under favourable conditions. When conditions were less favourable, mixed diets were most common, but diets dominated by non-euphausiid prey (fish or amphipods) still accounted for $15 \%$ of all observations. Macaroni penguins are capable of feeding on a variety of prey types during a foraging trip. Nonetheless, they generally forage in areas where aggregations of euphausiids occur predictably (Trathan et al. 2006, Waluda et al. 2010), and their non-euphausiid prey also tend to form aggregations. This tendency to feed on aggregated prey could, in itself, explain the high frequency of single-prey-type-dominated diets. We were unable to formally test the hypothesis that macaroni penguins are prey switchers by the above definition, but it is clear that they generally specialise on a single prey type during a trip. This provides some evidence for a sigmoidal functional response and a clear indication that their diets are not linear reflections of the relative density of different prey types in their foraging habitat. Cury et al. (2011) did not include this type of functional response in the analysis leading to their proposed ecosystem-based management reference point to account for the feeding requirements of seabirds. We suggest that sigmoidal functional responses should be included in such analyses.

\section{Inter-annual variability in diets}

In years in which there was a lower proportion of Euphausia superba in the diet, a corresponding increase in the frequency of Themisto gaudichaudii was observed. It is not clear whether this reflects the relative abundance of the 2 species in the local ecosystem or is an artefact of the population variability in E. superba described above. It is possible that this apparent switch could be related to the influx of different prey types caused by oceanographic variability, with $T$. gaudichaudii replacing E. superba in the environment close to South Georgia. This is linked to the location of the Southern Antarctic Circumpolar Front (SACCF) with warm (T. gaudichaudii, Krefftichthys anderssoni) and cold water (E. superba, Electrona carlsbergi) assemblages occurring to the north and south respectively of the SACCF between the South Orkneys and South Georgia (Ward et al. 2012). There is evidence of co-occurrence of these 'warm' and 'cold' water species in the diet of penguins. A total of 80 diet samples contained $K$. anderssoni of which $64(80 \%)$ also contained T. gaudichaudii, and all 8 diet samples containing E. carlsbergi also contained E. superba. Oceanographic variability has been linked with prey diversity in the diets of $\mathrm{Eu}$ dyptes spp. penguins at Marion Island (Brown et al. 1990), and have been suggested as a driver of prey variability in seabird diets in a variety of ecosystems elsewhere (Frederiksen et al. 2007, Montevecchi 2007, Springer et al. 2007, Thayer \& Sydeman 2007).

\section{Dietary influences on fledging mass}

We used fledging mass as an indicator of the net benefits of foraging. Our results show that these net benefits are more strongly related to the energy content of euphausiids in the diet than to Euphausia superba in particular or the total energy content of all prey in general. The latter is a description of the gross benefits of foraging, but our results suggest that the costs per unit energy vary between prey types. One of the major costs is the time taken to locate prey. Macaroni penguin foraging trip duration (mean $\pm \mathrm{SD}$ ) can vary between $5 \pm 4$ and $24 \pm 16 \mathrm{~h}$ during the crèche period, with penguins making longer trips or travelling a greater maximum distance from the colony during years of reduced E. superba availability (Trathan et al. 2006). There is an energy cost associated with pursuing and subduing prey, which tends to increase with prey size and mobility. There are also costs associated with digestion. Indeed, not all of the energy content of prey is available to the predator as some of it is associated with indigestible structures such as chitin. Fig. 7 shows that net benefits were lowest in 1994 and 2009 even though the gross energy content was above average in 2009. The majority of the gross energy came from amphipods in these years. 2004 was also characterised by above-average gross energy, in this case derived mainly from fish, and below average net benefits. It appears that the costs to a macaroni penguin of a unit of energy are generally higher for amphipods and fish than they are for euphausiids. Despite the lack of available information on costs, the high correlation between the modelled and observed values for fledging weights indicates the strong dependence of macaroni penguin reproductive output on the availability of euphausiids.

\section{CONCLUSIONS}

This study confirms that at South Georgia, crustaceans, particularly Euphausia superba, are 
the most important component of the diet of macaroni penguins, although the amount of E. superba can be very variable from year to year. The entire suite of land-based predator species monitored at Bird Island (macaroni and gentoo penguins, blackbrowed albatrosses and Antarctic fur seals) as part of CEMP are often described as 'krill-dependent predators' (Croxall \& Prince 1987, Veit et al. 1993, Reid et al. 1999a). None of the Bird Island species is an obligate euphausiid feeder (Reid \& Arnould 1996, Croxall et al. 1997, 1999). While euphausiids make up a greater proportion of the macaroni penguin diet than that of other species at Bird Island (Croxall et al. 1997, 1999), they are unimportant in the diets of some macaroni penguin populations elsewhere (Croxall \& Furse 1980, Green et al. 1998) and in the closely related royal penguins at Macquarie Island (Horne 1985, Hindell 1988, Hull 1999). At Bird Island, however, our results support the characterisation of the macaroni penguin population as 'krill dependent'. Fledging mass is strongly dependent on the euphausiid component of the diet; this dependence appears to relate to the availability of euphausiids in general rather than E. superba in particular. Although macaroni penguins were capable of feeding on alternative prey, fledging weight was below average in all 4 years in which euphausiids composed less than half of the diet. We do not have any data on post-fledging mortality, but it is likely that the fitness of a fledgling is positively related to its weight (Van Heezik \& Davis 1990, Olsson 1997, Moreno et al. 1999, McClung et al. 2004). This raises the possibility that macaroni penguins might commit the Concorde fallacy (Dawkins \& Carlisle 1976) when E. superba is scarce: that is, foraging to feed an underweight offspring might reduce the parent's fitness compared to foraging to feed itself. The dependence of individual fitness on the availability of euphausiids also supports the hypothesis that localised specialisation on euphausiids has enabled macaroni penguins to become the most numerous avian predator on Bird Island (Barlow et al. 2002, Trathan et al. 2012), and consequently euphausiid availability is the main factor limiting population size. There is substantial uncertainty about the future availability of E. superba with some studies suggesting that climate change could cause a catastrophic decline (e.g. Murphy et al. 2007b). Our results, and those of Hill et al. (2012), suggest that macaroni penguins at South Georgia would be particularly vulnerable to such a decline.
Acknowledgements. We thank all members of the Bird Island science team, past and present, who have sampled macaroni penguin diets over the last 3 decades, with particular thanks to D. Briggs. Thanks also to N. Ratcliffe, G. Tarling, I. Staniland, E. Murphy, S. Fielding and 3 anonymous reviewers for useful advice and comments on an earlier draft. This work is a contribution to the Ecosystems Programme at the British Antarctic Survey.

\section{LITERATURE CITED}

Adams NJ, Brown CR (1989) Dietary differentiation and trophic relationships in the sub-Antarctic penguin community at Marion Island. Mar Ecol Prog Ser 57:249-258

Agnew DJ (1997) The CCAMLR Ecosystem Monitoring Programme. Antarct Sci 9:235-242

Barlow KE, Croxall JP (2002) Seasonal and interannual variation in foraging range and habitat of macaroni penguins Eudyptes chrysolophus at South Georgia. Mar Ecol Prog Ser 232:291-304

Barlow KE, Boyd IL, Croxall JP, Reid K, Staniland IJ, Brierley AS (2002) Are penguins and seals in competition for Antarctic krill at South Georgia? Mar Biol 140:205-213

> Boyd IL (2002) Estimating food consumption of marine predators: Antarctic fur seals and macaroni penguins. J Appl Ecol 39:103-119

> Boyd IL, Murray AWA (2001) Monitoring a marine ecosystem using responses of upper trophic level predators. J Anim Ecol 70:747-760

Brooke MdeL (2004) The food consumption of the world's seabirds. Proc Biol Sci 271(Suppl 4):S246-S248

> Brown CR, Klages NT (1987) Seasonal and annual variation in diets of macaroni (Eudyptes chrysolophus chrysolophus) and southern rockhopper (E. chrysocome chrysocome) penguins at sub-Antarctic Marion Island. J Zool 212:7-28

Brown CR, Klages NT, Adams NJ (1990) Short and mediumterm variation in the diets of penguins at Marion Island. S Afr J Antarct Res 20:13-20

CCAMLR (Commission For The Conservation Of Antarctic Marine Living Resources) (2004) CCAMLR Ecosystem Monitoring Program (CEMP) Standard Methods. CCAMLR, Hobart (available at www.ccamlr.org/en/ document/science/cemp-standard-methods)

Cherel Y, Ridoux V (1992) Prey species and nutritive value of food fed during summer to king penguin Aptenodytes patagonica chicks at Possession Island, Crozet Archipelago. Ibis 134:118-127

> Ciancio JE, Pascual MA, Beauchamp DA (2007) Energy density of Patagonian aquatic organisms and empirical predictions based on water content. Trans Am Fish Soc 136:1415-1422

Clarke A (1980) The biochemical composition of krill, Euphausia superba Dana, from South Georgia. J Exp Mar Biol Ecol 43:221-236

Clarke A, Prince PA (1980) Chemical composition and calorific value of food fed to mollymauk chicks Diomedia melanophris and D. chrysostoma at Bird Island, South Georgia. Ibis 122:488-494

> Clarke A, Clarke MR, Holmes LJ, Waters TD (1985) Calorific values and elemental analysis of eleven species of oceanic squids (Mollusca: Cephalopoda). J Mar Biol Assoc UK 65:983-986

Clarke MR (1986) A handbook for the identification of 
cephalopod beaks. Clarendon Press, Oxford

Crawford RJM, Cooper J, Dyer BM (2003) Population of the Macaroni penguin Eudyptes chrysolophus at Marion Island, 1994/95-2002/03, with information on breeding and diet. Afr J Mar Sci 25:475-486

Croxall JP, Furse JR (1980) Food of chinstrap penguins Pygoscelis antarctica and macaroni penguins Eudyptes chrysolophus at Elephant Island Group, South Shetland Islands. Ibis 122:237-245

$>$ Croxall JP, Prince PA (1980) The food of gentoo penguins Pygoscelis papua and macaroni penguins Eudyptes chrysolophus at South Georgia. Ibis 122:245-253

Croxall JP, Prince PA (1987) Seabirds as predators on marine resources, especially krill at South Georgia. In: Croxall JP (ed) Seabirds: feeding ecology and role in marine ecosystems. Cambridge University Press, Cambridge, p 347-368

> Croxall JP, Prince PA (1996) Cephalopods as prey. I. Seabirds. Philos Trans R Soc Lond B Biol Sci 351:1023-1043

Croxall JP, Prince PA, Hunter I, McInnes SJ, Copestake PG (1984) The seabirds of the Antarctic Peninsula, islands of the Scotia Sea, and Antarctic continent between $80^{\circ} \mathrm{W}$ and $20^{\circ} \mathrm{W}$ : their status and conservation. In: Croxall JP, Evans PGH, Schreiber RW (eds) Status and conservation of the world's seabirds. International Council for Bird Preservation, Cambridge, p 637-666

> Croxall JP, Davis RW, O'Connell MJ (1988a) Diving patterns in relation to diet of gentoo and macaroni penguins at South Georgia. Condor 90:157-167

Croxall JP, McCann TS, Prince PA, Rothery P (1988b) Reproductive performance of seabirds and seals at South Georgia and Signy Island, South Orkney Islands, 1976-1987: implications for Southern Ocean monitoring studies. In: Sahrhage D (ed) Antarctic Ocean and resources variability. Springer, Berlin, p 261-285

> Croxall JP, Briggs DR, Kato A, Naito Y, Watanuki Y, Williams TD (1993) Diving pattern and performance in the macaroni penguin Eudyptes chrysolophus. J Zool (Lond) 230:31-47

Croxall JP, Prince PA, Reid K (1997) Dietary segregation of krill-eating South Georgia seabirds. J Zool (Lond) 242: 531-556

> Croxall JP, Reid K, Prince PA (1999) Diet, provisioning and productivity responses of marine predators to differences in availability of Antarctic krill. Mar Ecol Prog Ser 177: 115-131

- Cury PM, Boyd IL, Bonhommeau S, Anker-Nilssen T and others (2011) Global seabird response to forage fish depletion-one-third for the birds. Science 334: 1703-1706

> Dawkins R, Carlisle TR (1976) Parental investment, mate desertion and a fallacy. Nature 262:131-133

> Deagle BE, Gales NJ, Evans K, Jarman SN, Robinson S, Trebilco R, Hindell MA (2007) Studying seabird diet through genetic analysis of faeces: a case study on macaroni penguins (Eudyptes chrysolophus). PLoS ONE 2:e831

> Donnelly J, Torres JJ, Hopkins TL, Lancraft TM (1990) Proximate composition of Antarctic mesopelagic fishes. Mar Biol 106:13-23

> Frederiksen M, Mavor RA, Wanless S (2007) Seabirds as environmental indicators: the advantages of combining data sets. Mar Ecol Prog Ser 352:205-211

Green K, Williams R, Green MG (1998) Foraging ecology and diving behaviour of macaroni penguins Eudyptes chrysolophus at Heard Island. Mar Ornithol 26:27-34
Hart T, Coulson T, Trathan PN (2010) Time series analysis of biologging data: autocorrelation reveals periodicity of diving behaviour in macaroni penguins. Anim Behav 79:845-855

> Hill SL, Reid K, North AW (2005) Recruitment of mackerel icefish (Champsocephalus gunnari) at South Georgia indicated by predator diets and its relationship with sea surface temperature. Can J Fish Aquat Sci 62:2530-2537

> Hill SL, Keeble K, Atkinson A, Murphy EJ (2012) A foodweb model to explore uncertainties in the South Georgia shelf pelagic ecosystem. Deep-Sea Res II 59-60:237-252

- Hindell MA (1988) The diet of the royal penguin Eudyptes schlegeli at Macquarie Island. Emu 88:219-226

Holling CS (1959) Some characteristics of simple types of predation and parasitism. Can Entomol 91:385-398

Horne RSC (1985) Diet of royal and rockhopper penguins at Macquarie Island. Emu 85:150-156

Hull CL (1999) Comparison of the diets of breeding royal (Eudyptes schlegeli) and rockhopper (Eudyptes chrysocome) penguins on Macquarie Island over three years. J Zool (Lond) 247:507-529

Jablonski B (1985) The diet of penguins on King George Island, South Shetland Islands. Acta Zool Cracov 29: 177-186

Klages NTW, Gales RP, Pemberton D (1989) Dietary segregation of macaroni and rockhopper penguins at Heard Island. Aust Wildl Res 16:599-604

Lea MA, Nichols PD, Wilson G (2002) Fatty acid composition of lipid-rich myctophids and mackerel icefish (Champsocephalus gunnari) - Southern Ocean food-web implications. Polar Biol 25:843-854

McClung MR, Seddon PJ, Massaro M, Setiawan AN (2004) Nature-based tourism impacts on yellow-eyed penguins Megadyptes antipodes: Does unregulated visitor access affect fledging weight and juvenile survival? Biol Conserv 119:279-285

Miller AK, Trivelpiece WZ (2007) Cycles of Euphausia superba recruitment evident in the diet of pygoscelid penguins and net trawls in the South Shetland Islands, Antarctica. Polar Biol 30:1615-1623

> Montevecchi WA (2007) Binary dietary responses of northern gannets Sula bassana indicate changing food web and oceanographic conditions. Mar Ecol Prog Ser 352: 213-220

> Moreno J, Barbosa A, De León A, Fargallo JA (1999) Phenotypic selection on morphology at independence in the chinstrap penguin Pygoscelis antarctica. J Evol Biol 12: 507-513

Murdoch WW (1969) Switching in general predators: experiments on predator specificity and stability of prey populations. Ecol Monogr 39:335-354

> Murphy EJ, Reid K (2001) Modelling Southern Ocean krill population dynamics: biological processes generating fluctuations in the South Georgia ecosystem. Mar Ecol Prog Ser 217:175-189

> Murphy EJ, Watkins JL, Trathan PN, Reid K and others (2007a) Spatial and temporal operation of the Scotia Sea ecosystem: a review of large-scale links in a krill centred food web. Philos Trans R Soc Lond B Biol Sci 362: 113-148

Murphy EJ, Trathan PN, Watkins JL, Reid K and others (2007b) Climatically driven fluctuations in Southern Ocean ecosystems. Proc Biol Sci 274:3057-3067

Olsson O (1997) Effects of food availability on fledging condition and post-fledging survival in king penguin chicks. 
Polar Biol 18:161-165

Pichegru L, Ropert-Coudert Y, Kato A, Takahashi A, Dyer BM, Ryan PG (2011) Diving patterns of female macaroni penguins breeding on Marion Island, South Africa. Polar Biol 34:945-954

R Development Core Team (2011) R: a language and environment for statistical computing. R Foundation for Statistical Computing, Vienna, Austria

Reid K, Arnould JPY (1996) The diet of Antarctic fur seals Arctocephalus gazella during the breeding season at South Georgia. Polar Biol 16:105-114

Reid K, Croxall JP (2001) Environmental response of upper trophic-level predators reveals a system change in an Antarctic marine ecosystem. Proc Biol Sci 268:377-384

Reid K, Croxall JP, Prince PA (1996) The fish diet of blackbrowed albatross Diomedea melanophris and greyheaded albatross D. chrysostoma at South Georgia. Polar Biol 16:469-477

Reid K, Barlow KE, Croxall JP, Taylor RI (1999a) Predicting changes in the Antarctic krill, Euphausia superba, population at South Georgia. Mar Biol 135:647-652

Reid K, Watkins JL, Croxall JP, Murphy EJ (1999b) Krill population dynamics at South Georgia 1991-1997, based on data from predators and nets. Mar Ecol Prog Ser 177: 103-114

Reid K, Murphy EJ, Loeb V, Hewitt RP (2002) Krill population dynamics in the Scotia Sea: variability in growth and mortality within a single population. J Mar Syst 36:1-10

Reid K, Croxall JP, Briggs DR, Murphy EJ (2005a) Antarctic ecosystem monitoring: quantifying the response of ecosystem indicators to variability in Antarctic krill. ICES J Mar Sci 62:366-373

Reid K, Hill SL, Diniz TCD, Collins MA (2005b) Mackerel icefish Champsocephalus gunnari in the diet of upper trophic level predators at South Georgia: implications for fisheries management. Mar Ecol Prog Ser 305: 153-161

Reid K, Davis D, Staniland IJ (2006) Spatial and temporal variability in the fish diet of Antarctic fur seal (Arctocephalus gazella) in the Atlantic sector of the Southern Ocean. Can J Zool 84:1025-1037

Ridoux V (1994) The diets and dietary segregation of seabirds at the Subantarctic Crozet Islands. Mar Ornithol 22:1-192

Rodhouse PG, Prince PA, Clarke MR, Murray AWA (1990) Cephalopod prey of the grey-headed albatross Diomedea chrysostoma. Mar Biol 104:353-362

Springer AM, Byrd GV, Iverson SJ (2007) Hot oceanography: planktivorous seabirds reveal ecosystem responses to warming of the Bering Sea. Mar Ecol Prog Ser 352: 289-297

Staniland IJ, Boyd IL, Reid K (2007) An energy-distance

Editorial responsibility: Jacob González-Solís,

Barcelona, Spain trade-off in a central-place forager, the Antarctic fur seal (Arctocephalus gazella). Mar Biol 152:233-241

- Thayer JA, Sydeman WJ (2007) Spatio-temporal variability in prey harvest and reproductive ecology of a piscivorous seabird, Cerorhinca monocerata, in an upwelling system. Mar Ecol Prog Ser 329:253-265

Tierney M, Hindell MA, Goldsworthy S (2002) Energy content of mesopelagic fish from Macquarie Island. Antarct Sci 14:225-230

> Torres JJ, Donnelly J, Hopkins TL, Lancraft TM, Aarset AV, Ainley DG (1994) Proximate composition and overwintering strategies of Antarctic micronektonic crustacea. Mar Ecol Prog Ser 113:221-232

- Trathan PN, Green C, Tanton JL, Peat H, Poncet J, Morton A (2006) Foraging dynamics of macaroni penguins $E u-$ dyptes chrysolophus at South Georgia during broodguard. Mar Ecol Prog Ser 323:239-251

- Trathan PN, Ratcliffe N, Masden EA (2012) Ecological drivers of change at South Georgia: the krill surplus, or climate variability? Ecography (in press) doi: 10.1111/ j.1600-0587.2012.07330.x

Vanella FA, Calvo J, Morriconi ER, Aureliano DR (2005) Somatic energy content and histological analysis of the gonads in Antarctic fish from the Scotia Arc. Sci Mar 69:305-316

Van Heezik Y, Davis L (1990) Effects of food variability on growth rates, fledging sizes and reproductive success in the yellow-eyed penguin Megadyptes antipodes. Ibis 132:354-365

> Veit RR, Silverman ED, Everson I (1993) Aggregation patterns of pelagic predators and their principal prey, Antarctic krill, near South Georgia. J Anim Ecol 62: 551-564

Waluda CM, Collins MA, Black AD, Staniland IJ, Trathan PN (2010) Linking predator and prey behaviour: contrasts between Antarctic fur seals and macaroni penguins at South Georgia. Mar Biol 157:99-112

> Ward P, Atkinson A, Venables HJ, Tarling GA and others (2012) Food web structure and bioregions in the Scotia Sea: a seasonal synthesis. Deep-Sea Res II 59-60: 253-266

Williams TD (1991) Foraging ecology and diet of gentoo penguins Pygoscelis papua at South Georgia during winter and an assessment of their winter prey consumption. Ibis 133:3-13

Williams TD (1995) The penguins. Oxford University Press, Oxford

Wilson RP (1984) An improved stomach pump for penguins and other seabirds. J Field Ornithol 55:109-112

> Xavier JCC, Croxall JP, Reid K (2003) Inter-annual variation in the diets of 2 albatross species at South Georgia: implications for breeding performance. Ibis 145:593-610

Submitted: April 11, 2012; Accepted: July 5, 2012

Proofs received from author(s): September 25, 2012 